\title{
Adenoma of the Colon with Intramucosal Adenocarcinoma
}

National Cancer Institute

\section{Source}

National Cancer Institute. Adenoma of the Colon with Intramucosal Adenocarcinoma.

NCI Thesaurus. Code C27413.

An intramucosal malignant glandular epithelial infiltrate in a colonic adenoma. There is no evidence of submucosal invasion. 